\title{
SMALL GROUP DISCUSSION BERBASIS PEER ASSESMENT: MENINGKATKAN KETERAMPILAN KOMUNIKASI LISAN CALON GURU SEKOLAH DASAR
}

\author{
Irma Pravitasari \\ Christina Ismaniati
}

\author{
Program Studi Pendidikan Dasar \\ Universitas Negeri Yogyakarta \\ e-mail: Irmapravita.2017@student.uny.ac.id
}

Artikel diterima: 1 Januari 2019; disetujui: 31 Mei 2019

\begin{abstract}
This research is conducted to improve oral communication skills of elementary school pre-service teachers through the application of small group discussion methods based on peer assessment. This research is a classroom action research. Data collection techniques used are peer assessment and observation. Pre-action conditions show the percentage of students who meet the criteria for skilled oral communication by $22.5 \%$, after the first cycle of action the percentage of students increases to $52.2 \%$ and returns to increase in the action of cycle II with a percentage of $75 \%$. Based on the results of these studies, it is known that the application of the peer group based small group discussion method can improve the oral communication skills of elementary school pre-service teachers.
\end{abstract}

Keywords: small group discussion, peer assessment, oral communication skills, elementary school pre-service teachers

\begin{abstract}
Abstrak: Penelitian ini dilakukan untuk meningkatkan keterampilan komunikasi lisan calon guru sekolah dasar melalui penerapan metode small group discussion berbasis peer assesment. Penelitian ini merupakan penelitian tindakan kelas. Teknik pengumpulan data yang digunakan adalah peer assesment dan observasi. Kondisi pratindakan menunjukkan persentase mahasiswa yang memenuhi kriteria terampil berkomunikasi lisan sebesar $22,5 \%$, setelah tindakan siklus I jumlah persentase mahasiswa meningkat menjadi 52,2\% dan kembali meningkat pada tindakan siklus II dengan persentase $75 \%$. Berdasarkan hasil penelitian tersebut maka diketahui bahwa penerapan metode small group discussion berbasis peer assesment dapat meningkatan keterampilan komunikasi lisan calon guru sekolah dasar.
\end{abstract}

Kata kunci: small group discussion; peer assesment; keterampilan komunikasi lisan, calon guru sekolah dasar

Kehidupan di abad 21 menuntut siapapun yang hidup di zamannya untuk menguasai berbagai bidang keahlian. Keahlian merupakan kemampuan untuk melakukan sesuatu terhadap sebuah peran (Marcus \& Curt, 2017). Setiap keahlian tentunya tidak dapat diperoleh secara instan. Mahir dalam suatu bidang memer-lukan proses belajar yang dilakukan secara berkesinambungan. Pendidikan berperan untuk memfasilitasi proses belajar siswa dalam mengembangkan potensi dirinya sehingga ia dapat mahir dalam suatu hal, pendidikan juga membelajarkan siswa dengan berbagai keterampilan agar ia dapat menjadi generasi masa depan yang mampu bertahan di tengah dinamika perubahan zaman. Sebagaimana peran lembaga pen-didikan yaitu, "to prepare students for the types of skills needed for them to live and work in the 21 st century" (Dass, 2014). 
Guru merupakan subjek yang paling berpengaruh di dunia pendidikan, karena guru berperan sebagai pengendali utama dalam proses pembelajaran. Sebagaimana yang telah dijelaskan bahwa kemampuan tidak dapat diperoleh secara instan, begitu pula keterampilan guru untuk dapat mengajar dengan profesional di abad 21. Guru maupun calon guru Sekolah Dasar hingga sekolah menengah diwajibkan menempuh pendidikan hingga jenjang sarjana (S1). Disinilah peran penting pendidikan tinggi untuk mencetak calon pendidik menjadi guru profesional dengan kecakapan yang mumpuni di abad 21.

Beberapa organisasi dan pakar telah mengidentifikasi berbagai keterampilan yang perlu dimiliki di abad 21. US-based Apollo Education Group mengidentifikasi sepuluh keterampilan yang perlu dimiliki di abad 21 yaitu keterampilan berfikir kritis, komunikasi, kepemimpinan, kolabo-rasi, kemampuan beradaptasi, produktifitas dan akuntabilitas, inovasi, kewarganegara-an global, kemampuan dan jiwa enterpreneurship dan kemampuan untuk mengelola informasi (Barry, 2012).

Assessment and Teaching of 21 st Century Skills mengelompokkan keteram-pilan yang perlu dimiliki di abad 21 dalam empat penggolongan yaitu way of thingking, way of working, tool for working dan skill living in the world (Griffin, McGaw, \& Care, 2012). Way of thingking meliputi kemampuan pemecahan masalah, kreativitas, berpikir kritis, berino-vasi dan membuat keputusan. Way of working meliputi keterampilan dalam komunikasi, kolaborasi dan kerjasama. Tool for working meliputi kesadaran sebagai warga global maupun lokal, pengembangan kualitas hidup dan karir, serta adanya tanggung jawab sebagai pribadi maupun sosial. Skill for living in the world meliputi kemampuan literasi, penguasaan teknologi informasi dan komunikasi serta kemampuan untuk belajar dan bekerja melalui sosial media digital.

US-based Partnership for 21st Century Skills (P21), menyebutkan empat kompetensi yang diperlukan di abad 21 yang dikenal dengan "The 4C's". 4C merupakan kependekan dari communication, collaboration, critical thingking dan creativity. Sedangkan (Wagner, 2008) menyebutkan tujuh keterampilan yang perlu dimiliki di abad 21 yang meliputi: (1) critical thinking dan problem solving, (2) kolaborasi dan kepemimpinan, (3) keterampilan komuni-kasi baik secara oral maupun tulisan, (4) memiliki rasa ingin tahu dan imajinasi, (5) inisiatif dan berjiwa enterprenour, (6) ketangkasan dan kemampuan beradaptasi, (7) memiliki keterampilan mengakses dan menganalisis informasi. Berdasarkan berbagai pendapat para ahli dan organisasi tersebut terdapat satu keterampilan yang selalu muncul dalam setiap pendapat para ahli yaitu keterampilan komunikasi. Oleh karena itu, analisis peneliti menunjukkan bahwa keterampilan komunikasi merupakan keterampilan vital yang perlu dimiliki di abad 21.

Komunikasi dapat diartikan sebagai proses penyampaian informasi dari satu pihak ke pihak yang lain dimana informasi atau pesan tersebut dapat diterima dengan baik oleh penerima pesan. Seseorang yang memiliki keterampilan mengkomunikasi-kan adalah ia yang mampu menggunakan dan memilih bahasa yang tepat sehingga mudah dipahami oleh semua orang, dapat meyakinkan para penerima pesan, mampu menyampaikan pesan dengan singat, jelas dan sesuai dengan target yang diharapkan. Keuntungan dari penguasaan keterampilan mengkomunikasikan selain dapat menyampaikan informasi juga dapat mempengaruhi penerima untuk mengikuti atau setidaknya tidak melakukan penolakan terhadap infor-masi yang diberikan. Komunikasi merupakan keterampilan yang sangat penting dan menjadi salah satu kunci sukses dalam bisnis maupun profesi apapun (Lunenburg, 2010).

Saat ini kita berada pada suatu masa dimana seseorang tidak dapat bekerja sendirian, setiap orang membutuhkan bantuan orang lain untuk menyelesaikan suatu pekerjaan, oleh kerena itu kemampu-an berkomunikasi menjadi hal yang perlu dikuasai. Perkembangan teknologi di bidang komunikasi dan informasi menjadi-kan kemampuan berkomunikasi tidak hanya perlu dikuasai namun patut menjadi prioritas dalam penguasaan keterampilan abad 21. Kemampuan komunikasi mencakup keterampilan dalam menyampaikan pendapat, gagasan maupun opini dengan jelas, mengajukan perintah dengan jelas serta mampu memberikan motivasi kepada orang lain melalui keterampilan berbicara (Zubaidah, 2017).

Komunikasi terdiri dari dua jenis yaitu komunikasi lisan dan tulisan. Komunikasi lisan menggunakan bahasa lisan dimana organ tubuh yang diperlukan lebih condong pada alat dengar, penerimaan bahasa lisan oleh pendengar secara temporal dan langsung, dalam bahasa lisan terdapat 
prosodi dan diperlukan adanya balikan secara langsung dalam proses komunikasinya. Berbeda dengan komunikasi tertulis yang melibatkan bahasa tulis dimana organ tubuh yang diperlukan lebih condong pada alat penglihatan, penerimaan bahasa tulis secara permanen dan penerimaannya dapat ditunda, dalam bahasa tulis terdapat tanda baca dan kadang-kadang balikan dapat ditunda atau bahkan tidak ada balikan (Mustadi, 2014).

Komunikasi akan terganggu apabila sikap penerima informasi kurang respect atau sedang dalam keadaan emosi sehingga pesan-pesan tidak bisa diterima dengan utuh. Komunikasi juga akan terhambat apabila situasi kurang kondusif seperti suasana yang bising. Selain itu kendala dalam proses komunikasi juga dapat disebabkan oleh pihak yang terlibat dalam proses komunikasi yang tidak mahir dalam mengkomunikasikan informasi, seperti penggunaan bahasa yang digunakan tidak atau kurang dapat dipahami oleh penerima pesan.

Lembaga pendidikan baik sekolah dan perguruan tinggi harus melatih dan mengembangkan keterampilan komunikasi para siswa maupun mahasiswanya untuk dapat berkomunikasi dengan baik. Keterampilan komunikasi diperlukan sebagai bekal untuk dapat diterima di pasar kerja dan mampu mendorong serta meningkat-kan kualitas institusi tempat mereka berkarir. Berdasarkan hal tersebut maka keterampilan komunikasi menjadi sangat penting bagi semua siswa maupun mahasiswa pada bidang studi apapun. Pembinaan kompetensi komunikasi menjadi mandat dalam proses pembelajaran pada semua subject metter (Van Roekel, 2014).

Keterampilan komunikasi guru juga dapat menciptakan pembelajaran dan pe-ngajaran yang berkualitas. Proses pembelajaran dan pengajaran yang berkualitas didasarkan pada hubungan yang kuat, saling menghormati dan menjaga kepercayaan (Zubaidah, 2017). Guru abad 21 tidak hanya dituntut untuk mampu mengajar dan mengelola kelas dengan baik namun guru abad 21 juga harus mampu membangun hubungan baik dengan siswa maupun kemunitas sekolah (Darling-Hammond, 2006). Hubungan baik antara guru dan siswa dapat dibentuk melalui keterampilan berkomunikasi.

Pentingnya penguasaan keterampilan komunikasi di abad 21 menjadikan pendidikan dituntut untuk dapat mengembang-kan keterampilan komunikasi peserta didik. Namun kenyataan di lapangan masih ditemui kondisi dimana keterampilan komunikasi siswa masih rendah. Salah satu temuan dalam penelitian yang dilakukan oleh (Trilling \& Fadel, 2009) menunjukkan bahwa tamatan sekolah menengah, diploma dan pendidikan tinggi masih kurang kompeten dalam hal komunikasi oral maupun tertulis. Hal ini serupa dengan hasil observasi pratindakan yang dilakukan oleh peneliti terhadap 40 mahasiswa calon guru sekolah dasar di Universitas PGRI Yogyakarta yang menunjukkan rendahnya keterampilan komunikasi lisan mahasiswa calon guru Sekolah Dasar.

Berdasarkan hasil pengamatan, kegiatan perkuliahan lebih didominasi oleh anggota kelompok yang bertugas untuk mempresentasikan materi yang telah dibagikan sebelumnya. Ketika kelompok penyaji memaparkan materi, 55\% mahasiswa kurang memperhatikan dan 22.5\% mahasiswa tidak memperhatikan. Penyajian materi oleh kelompok penyaji kurang inter-aktif karena penyaji cenderung membaca teks materi dengan volume suara yang rendah dan tidak menjelaskan isi materi menggunakan bahasa sendiri. Kegiatan diskusi dilakukan melalui pemberian kesempatan kepada mahasiswa untuk bertanya pada kelompok penyaji terkait materi yang disampaikan, namun dari 40 mahasiswa hanya terdapat 2 mahasiswa yang berani bertanya terkait materi yang disampaikan, sedangkan mahasiswa yang lain enggan untuk terlibat dalam kegiatan diskusi. Terlihat bahwa diskusi hanya sebatas kegiatan bertanya dan menjawab tanpa ada pembahasan lebih lanjut karena mahasiswa cenderung pasif dalam kegiatan diskusi. Berdasarkan data statistik hasil observasi pratindakan diperoleh data sebesar 5\% mahasiswa berada dalam kategori sangat terampil berkomunikasi, $17,5 \%$ mahasiswa dalam kategori terampil berkomunikasi, 25\% mahasiswa dalam kategori cukup terampil berkomunikasi dan $52,5 \%$ mahasiswa dalam kategori kurang terampil berkomunikasi.

Menyikapi permasalahan di atas diperlukan metode pembelajaran yang tepat. Memberikan perkuliahan kepada calon guru sekolah dasar untuk menjadi pendidik yang profesional tidak hanya sekedar memberikan pengetahuan kepada mahasiswa tentang proporsisi atau pengetahuan berbagai pendekatan dan strategi mengajar. Semakin berkembangnya teknologi infor-masi dan komunikasi di abad 21 ini, menjadikan pengetahuan 
tentang berbagai pendekatan dan strategi mengajar dapat diakses dengan mudah. Melalui gawai atau media informasi-komunikasi sejenis, mahasiswa dapat dengan mudah menjaring berbagai informasi up to date terkait pendekatan dan strategi mengajar. Hal ini tentunya menjadi tantangan tersendiri bagi dosen, tugas dosen tidak lagi sekedar menstransfer pengetahuan namun lebih berperan untuk mengkonstruk informasi dalam pikiran, mengkaitkan dan meng-interpretasikan ide-ide baru dengan yang telah diketahui sebelumnya, berkaitan dengan hal tersebut maka pembelajaran cooperative yang melibatkan proses diskusi, dialog, argumen dan juga debat sangat membantu dalam proses tersebut (McCann \& Radford, 1993).

Pembelajaran cooperative menjadi solusi untuk membelajarkan mahasiswa agar dapat menguasai keterampilan abad 21. Salah satu strategi pembelajaran cooperative yang dapat mengatasi rendahnya kete-rampilan komunikasi lisan mahasiswa adalah menggunakan metode Small Group Discussion (SGD). Proses pembelajaran dengan menciptakan sebuah kelompok be-lajar yang positif dan efektif dapat mendukung pembelajaran yang lebih men-dalam melalui perolehan konten penge-tahuan dan pengembangan keterampilan interpersonal dan intrapersonal (Pellegrino et al., 2012).

Metode pembelajaran SGD adalah rangkaian kegiatan belajar yang dilakukan oleh siswa dalam suatu kelompok kecil untuk mencapai tujuan pembelajaran yang telah dirumuskan. Metode SGD dilakukan de-ngan membagi siswa dalam kelompok-kelompok yang jumlah anggotanya antara empat sampai enam mahasiswa dalam satu kelompok yang bekerja terlepas dari guru (Slavin, 2011). SGD merupakan metode pembelajaran yang dilakukan dengan mengelompokkan siswa dalam kelompok kecil untuk berkerja sama dalam kegiatan diskusi, hal ini sesuai dengan salah satu prinsip dalam mengajarkan keterampilan abad-21 untuk menggalakkan kerja sama kelompok (Saavedra \& Opfer, 2012).

Penerapan metode diskusi kelompok kecil dilakukan dengan membagi keselu-ruhan mahasiswa di dalam kelas menjadi beberapa kelompok yang masing-masing kelompok terdiri dari 3-5 orang, penentuan anggota kelompok dipilih secara random. Dosen menyajikan masalah untuk setiap kelompok dan setiap kelompok akan mencoba memecahkan masalah tersebut. Pada akhir diskusi setiap kelompok melaporkan hasil diskusi kelompoknya dan dilanjutkan dengan menyimpulkan hasil diskusi bersama dosen. Setelah kesimpulan disampaikan, mahasiswa dan dosen melakukan refleksi atas kegiatan diskusi yang dilakukan. Kegiatan refleksi dapat berupa penilaian terhadap proses jalannya diskusi. Dosen dapat menggunakan respon siswa sebagai kesempatan untuk mengevaluasi kesiapan mereka untuk belajar lebih dalam dan memperkenalkan konsep-konsep baru yang sesuai dan menantang pemikiran mereka (Bolstad, 2011).

Penilaian dapat dilakukan dalam bentuk peer assesment. Peer assesment melibatkan teman sejawat dalam menilai pekerjaan rekan-rekan mereka dalam satu kelompok. Penilaian ini dapat digunakan sebagai umpan baik maupun refleksi untuk kemajuan kelompok maupun setiap anggota yang terlibat di dalamnya. Peer assesment, "can also involve more qualitative aspects and an emphasis on feedback relating to the criteria used rather than the grade" (Falchikov, 2003). Rekan dalam kelompok yang terlibat dalam peer assesment dapat meningkatkan reliabilitas penilaian. Seperti yang diung-kapkan oleh (Falchikov, 1991) "Peer assessment, however, increases the number of assessors involved and therefore increases the assessment reliability and reduces subjectivity". Studi penelitian melaporkan bahwa melalui peer assesment mahasiswa lebih terlibat dalam umpan balik dari rekan-rekan mereka daripada dari dosen mereka (Logan, 2009). Melalui peer assesment mahasiswa dapat mengembangkan aspek proses dalam pembelajaran mereka (Orsmond, Merry, \& Reiling, 1996) dan memungkinkan penilaian menjadi lebih transparan bagi mahasiswa (Roberts, 2005).

Keterlibatan mahasiswa dalam proses penilaian di akhir kegiatan diskusi menjadi bagian untuk mengemas kegiatan diskusi menjadi lebih efektif dan tepat sasaran untuk meningkatkan keterampilan komuni-kasi mahasiswa. Sebelum kegiatan diskusi, dosen memberikan penjelasan terkait peer assesment di akhir kegiatan diskusi. Dosen juga menjelaskan indikator penilaian keterampilan komunikasi yang akan dinilai oleh rekan dalam satu tim. Hal ini dilakukan untuk memotivasi mahasiswa agar terlibat aktif dan komunikatif selama diskusi berlangsung.

Penelitian tentang penilaian teman sebaya yang dilakukan selama lima tahun oleh (Nortcliffe, 2012) 
menunjukkan beberapa pengalaman diantaranya: (1) Adanya prasangka rasial dalam proses penilaian teman sebaya namun hanya ditemui sekali dalam satu kasus selama lima tahun penelitian, (2) Hanya satu kelompok di setiap tahun yang membutuhkan bim-bingan untuk melakukan penilaian teman sejawat karena adanya satu atau dua penilaian rekan yang tidak konsisten, (3) Satu dosen terlibat untuk menyelesaikan satu kelompok yang mengalami bentrokan kepribadian yang parah dan penilaian rekan yang tidak konsisten dengan mewa-wancari setiap siswa untuk memastikan refleksi sebenarnya dari kontribusi masing-masing individu terhadap kerja kelompok.

Pengembangan metode Small Group Discussion berbasis peer assesment bertumpu pada hasil penelitian (Nortcliffe, 2012) yang menunjukkan bahwa siswa dapat menilai diri mereka sendiri dan rekan-rekan mereka. "Can students assess themselves and their peers? The evidence suggests 'yes'. Peers can assess one another". Peer assesment dalam penelitian ini termasuk dalam penilaian formatif. Penilaian formatif terhadap teman sebaya dalam satu kelompok dapat memberikan umpan balik yang lebih efektif daripada umpan balik yang diberikan oleh dosen. Seperti hasil penelitian (Nortcliffe, 2012) yang menyatakan bahwa "Peer formative assessment can be an effective means of providing timely and detailed feedback to students and timely opportunities for the students to reflect upon their learning and understanding. Both current and previous students valued their peer formative feedback sometimes more than the feedback offered by their tutor"

Berdasarkan uraian di atas dapat diketahui bahwa terdapat permasalahan yaitu rendahnya keterampilan komunkasi lisan mahasiswa calon guru sekolah dasar. Oleh karena itu, penelitian ini dilaksanakan untuk melakukan tindakan berupa penerapan metode Small Group Discussion berbasis peer assesment dan untuk menguji hipotesis apakah metode Small Group Discussion berbasis peer assesment dapat meningkatkan keterampilan komunikasi lisan mahasiswa.

\section{METODE}

Penelitian ini termasuk dalam jenis classroom action research. Peneliti terlibat secara langsung dalam proses penelitian bersama kolaborator. Prosedur penelitian difokuskan pada pemberian tindakan sebagai solusi dari suatu permasalahan.
Pemberian tindakan dilakukan dengan menganalisis keadaan dan melihat kesenjangan antara kondisi yang diinginkan dengan kenyataan di lapangan kemudian merumuskan rencana pelaksanaan tindakan. Setelah itu peneliti terlibat secara penuh dalam melaksanakan rencana tindakan, melakukan observasi, menganalisis data yang diperoleh dan melaporkan hasil penelitian. Tindakan yang dilaksanakan dalam penelitian ini adalah penerapan metode Small Group Discussion (SGD) berbasis Peer Assesment. Desain penelitian tindakan kelas ini dilakukan dalam serang-kaian langkah yang berbentuk spiral dimana penelitian dilakukan dalam dua siklus dan di setiap siklus terdapat empat langkah penelitian yaitu, planning, acting, observing, dan reflecting.

Penelitian ini melibatkan mahasiswa calon guru sekolah dasar di Universitas PGRI Yogyakarta. Penelitian dilakukan pada mata kuliah Ilmu Pengetahuan Sosial di kelas A6 Semester 2 S1 Prodi Pendidikan Guru Sekolah Dasar, Fakultas Keguruan dan Ilmu Pendidikan, Universitas PGRI Yogyakarta tahun akademik 2018. Subjek penelitian berjumlah 40 mahasiswa, terdiri dari 6 mahasiswa laki-laki dan 34 mahasiswa perempuan.

Teknik pengumpulan data dalam penelitian ini ialah observasi dan peer asses-ment. Observasi dilakukan oleh peneliti pada saat pratindakan untuk mengamati proses perkuliahan serta mendeteksi ada-nya permasalahan di dalam kelas. Obser-vasi yang dilakukan berfokus pada aktivitas mahasiswa di dalam kelas. Teknik peer assesment dilakukan oleh setiap mahasiswa di akhir proses diskusi untuk menilai keterampilan komunikasi lisan antar teman dalam satu kelompok kecil. Gambar 1 menunjukkan lembar peer assesment.

Lembar peer assesment diberikan kepada setiap mahasiswa untuk menilai keterampilan komunikasi lisan yang meli-puti penilaian diri dan penilaian rekan dalam satu kelompok. Perolehan nilai keterampilan komunikasi lisan kemudian diakumulasikan dan dikategorikan dalam empat kriteria. Tabel 1 menunjukkan kriteria penilaian keterampilan komunikasi lisan.

Tabel 1. Kriteria Nilai Keterampilan Komunikasi Lisan

\begin{tabular}{cc}
\hline Rentang Nilai & Kategori \\
\hline $81-100$ & Baik \\
$71-80$ & Cukup \\
$61-70$ & Kurang \\
$01-60$ & Gagal \\
\hline
\end{tabular}




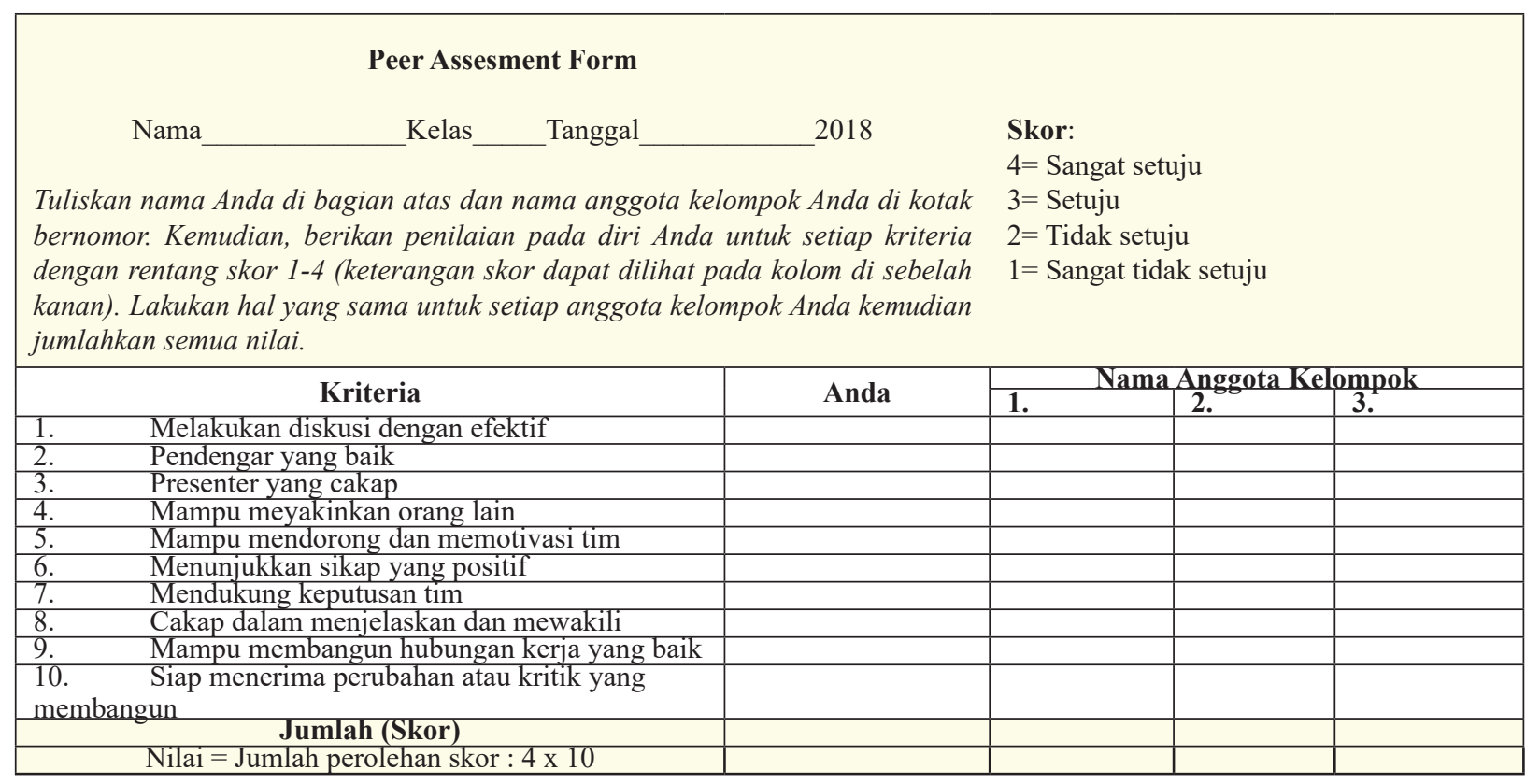

Gambar 1. Lembar Peer Assesment (Dikembangkan dari: Chad Manis, Teacher Written Eduware, LLC, 2012; Goldfinch, 1994; Lejk \& Wyvill, 2001)

Data dianalisis dengan teknik analisis secara interaktif. Teknik analisis yang digunakan dalam penelitian ini adalah analisis interaktif model Miles dan Huberman yang merupakan interaksi dari tiga komponen utama, yaitu reduksi data, penyajian data (display data), dan penarikan simpulan. (1) Reduksi data, merupa-kan proses pengumpulan data, seleksi, pemfokusan, penyederhanaan, dan abstrak-si data dari fieldnote, (2) Display data, merupakan penyajian data ke dalam sejumlah matriks atau daftar kategori, bentuk penya-jian data yang digunakan berupa teks naratif, (3) tahap terakhir adalah penarikan simpulan tentang peningkatan yang terjadi (Iskandar, 2013). Proses refleksi dilakukan pada setiap akhir siklus dalam penelitian ini. Refleksi digunakan untuk melihat hasil dari proses tindakan yang telah dilakukan. Refleksi dilakukan peneliti bersama kolaborator, hasil dari refleksi juga digunakan untuk menentukan proses tindak lanjut atau rencana selanjutnya pada siklus berikutnya untuk mencapai tujuan tindakan yaitu meningkatkan keterampilan komunikasi lisan mahasiswa.

\section{HASIL}

Penelitian ini dilaksanakan di kelas A6 S1 Program Studi Pendidikan Guru Seko-lah Dasar (PGSD) yang berlokasi di Kampus 2 Sonosewu, Kecamatan Kasihan, Kabupaten Bantul Yogyakarta. Subjek penelitian ini adalah seluruh mahasiswa yang berjumlah 40 orang mahasiswa. Obyek penelitian ini adalah keterampilan komunikasi lisan dalam perkuliahan Ilmu Pengetahuan Sosial 1 (IPS 1). Sebelum melaksanakan tindakan, peneliti melaku-kan kegiatan observasi pra tindakan. Hasil observasi pra tindakan tersebut menujuk-kan bahwa sebagian besar mahasiswa belum terampil dalam berkomunikasi secara lisan. Adapun indikator yang menjadi tolok ukur keterampilan komunikasi lisan mahasiswa adalah; (1) efektif dalam dis-kusi, (2) pendengar yang baik, (3) presenter yang cakap, (4) mampu meyakinkan orang lain, (5) mendorong dan memotivasi tim, (6) sikap positif, (7) mendukung keputusan tim, (8) kecakapan dalam menjelaskan dan mewakili, (9) mampu membangun hubungan kerja yang baik, (10) siap menerima perubahan atau kritik yang membangun.

Tabel 2 merupakan kategori ketercapaian kemampuan berdiskusi mahasiswa sebelum dilakukan tindakan (pratindakan).

Tabel 2. Data Nilai Keterampilan Komunikasi Lisan Mahasiswa Pratindakan

\begin{tabular}{|c|c|c|c|}
\hline Kategori & $\begin{array}{c}\text { Rentang } \\
\text { Nilai }\end{array}$ & Frekuensi & Persentase \\
\hline Terampil & $81-100$ & 2 & $5,0 \%$ \\
\hline Cukup & $71-80$ & 7 & $17,5 \%$ \\
\hline Kurang & $61-70$ & 10 & $25,0 \%$ \\
\hline Gagal & $01-60$ & 21 & $52,5 \%$ \\
\hline \multicolumn{2}{|c|}{ Jumlah } & 40 & $100 \%$ \\
\hline
\end{tabular}


Berdasarkan hasil observasi awal ter-sebut diperoleh data bahwa penguasaan keterampilan komunikasi lisan mahasiswa masih sangat kurang, sebesar $77.5 \%$ mahasiswa berada dalam kategori kurang dan gagal. Salah satu penyebabnya adalah pola pembelajaran mahasiswa yang masih belajar secara pasif dan berfokus pada penugasan. Kesadaran mahasiswa untuk aktif dalam kegitan perkuliahan melalui komunikasi lisan juga masih rendah, mahasiswa masih terlihat malu dan takut untuk mengutarakan pendapat maupun memberikan penjelasan terkaitmateriyang disampaikan. Walaupun perkuliahan telah dikemas dalam pembelajaran yang ber-pusat pada siswa melalui kegiatan presen-tasi, namun informasi yang disampaikan oleh kelompok presenter tidak komunikatif sehingga penerima pesan cenderung kurang memperhatikan dan pasif dalam kegiatan diskusi.

Rendahnya keterampilan komunikasi lisan mahasiswa tersebut merupakan suatu permasalahan yang membutuhkan solusi. Pemecahan masalah rendahnya keteram-pilan komunikasi lisan dalam penelitian ini yaitu dengan diterapkannya metode Small Group Discussion (SGD) berbasis peer assesment dalam proses perkuliahan untuk meningkatkan keterampilan komunikasi lisan mahasiswa yang masih berada dalam kategori kurang dan gagal.

\section{Pelaksanaan Siklus I}

Siklus I dilaksanakan dalam dua kali pertemuan tatap muka yang masing-masing pertemuan dilaksanakan selama 3 x 50 menit atau 3 SKS. Tahap pertama dalam siklus I adalah perencanaan. Langkahlangkah yang dilakukan dalam perencanaan yaitu melakukan analisis silabus perkuliahan, menentukan pokok bahasan pada pertemuan pertama dan kedua, menyusun Satuan Acara Perkulia-han (SAP) dengan mengintegrasikan meto-de Small Group Discussion berbasis peer assesment, dan menyusun instrumen berupa lembar penilaian teman sebaya serta lembar rekapitulasi nilai peer assesment dan lembar observasi kegiatan perkuliahan

Tahap kedua dalam siklus I yaitu pelaksanaan, langkah-langkah tindakan yang dilakukan yaitu; (1) Kelas dibagi dalam 10 kelompok kecil yang beranggotakan 4 orang mahasiswa tiap kelompok, (2) Setiap kelompok diberi bahan diskusi yang berbeda-beda namun masih dalam satu topik materi, (3) Dosen menjelaskan langkah diskusi dan peer assesment yang akan dilakukan, (4) Dosen menjelaskan aspek keterampilan komunikasi lisan yang akan dinilai dalam peer assesment (5) setiap kelompok berdiskusi sesuai dengan permasalahan dalam bahan diskusi yang diberikan, (6) perwakilan dari anggota kelompok menyampaikan hasil diskusi dan kelompok lain memberikan tanggapan, (7) pengambilan kesimpulan bersama, (8) penilaian keterampilan komunikasi lisan oleh rekan dalam satu kelompok.

Tahap ketiga dalam siklus I yaitu pengamatan, peneliti melakukan pengamatan terhadap aktivitas mahasiswa dalam proses perkuliahan menggunakan metode SGD berbasis peer assesment. Tahap terakhir dalam siklus I yaitu refleksi, refleksi dilakukan peneliti bersama kolaborator untuk mengevaluasi pelaksanaan tindakan pada siklus I, refleksi dilakukan dengan menganalisis proses pelaksanaan tindakan dan hasil peer assesment yang telah dilakukan. Refleksi digunakan untuk menentukan langkah perbaikan pada tindakan di siklus II.

Hasil refleksi terhadap proses pelak-sanaan tindakan pada siklus I yaitu pelaksanaan tindakan Small Group Discussion berjalan dengan lancar, maha-siswa dapat memahami instruksi dari dosen maupun peneliti terkait kegiatan diskusi yang dilakukan, penilaian teman sebaya dapat dilakukan dengan baik tanpa adanya prasangka rasial karena anggota kelompok ditentukan secara random dan tidak ada kelompok yang membutuhkan bimbingan khusus dalam pelaksanaan peer assesment. Proses diskusi berjalan lebih komunikatif, dengan hasil rata-rata nilai keterampilan komunikasi lisan mahasiswa melalui peer assesment disajikan dalam tabel 3 sebagai berikut.

\section{Tabel 3. Data Nilai Keterampilan Komunikasi Lisan Mahasiswa Siklus I}

\begin{tabular}{cccc}
\hline Kategori & $\begin{array}{c}\text { Rentang } \\
\text { Nilai }\end{array}$ & Frekuensi & Persentase \\
\hline Terampil & $81-100$ & 6 & $15,0 \%$ \\
Cukup & $71-80$ & 15 & $37,5 \%$ \\
Kurang & $61-70$ & 14 & $35,0 \%$ \\
Gagal & $01-60$ & 5 & $12,5 \%$ \\
\hline \multicolumn{2}{c}{ Jumlah } & 40 & $100 \%$ \\
\hline
\end{tabular}

Keterampilan komunikasi lisan maha-siswa mengalami peningkatan pada pelak-sanaan siklus I, terlihat dari penurunan persentase nilai keterampilan komunikasi lisan pada kategori kurang dan gagal yang semula sebesar $77.5 \%$ 
mengalami penu-runan menjadi $47.5 \%$. Peneliti bersama kolaborator memutuskan untuk melakukan upaya peningkatan keterampilan komuni-kasi lisan mahasiswa dalam persentase yang lebih besar. Upaya yang dilakukan yaitu dengan mendeteksi kekurangan dan kelemahan pada pelaksanaan siklus I. Hasil analisis menunjukkan bahwa, pelaksanaan tindakan pada siklus I memiliki keku-rangan dalam hal pengkondisian ruang dan pengalokasian waktu, peneliti dan kolabo-lator memutuskan untuk memberikan alo-kasi waktu yang lebih lama pada saat penilaian teman sebaya, karena pada pelaksanaan tindakan siklus I, waktu banyak terbuang saat mengkondisikan ruang kelas untuk kegiatan diskusi, sehingga tahap akhir yaitu penilaian memiliki waktu yang sangat terbatas (selama 5-10 menit), sehingga mahasiswa kurang menganalisis butirbutir penilaian. Hasil dari penilaian peer assesment pada siklus I juga disampaikan kepada mahasiswa secara pribadi malalui e-mail, sehingga mahasiswa dapat mengkoreksi kelemahannya dalam proses diskusi terutama dalam keterampilan komunikasi lisan. Selain menyampaikan hasil penilaian, dosen juga melampirkan pernyataan berupa motivasi dan penguatan pada lembar hasil penilaian mahasiswa.

\section{Pelaksanaan Siklus II}

Tahap pelaksanaan siklus II sama dengan pelaksanaan siklus I karena desain penelitian ini berbentuk spiral, ketika semua tahap dalam satu siklus telah sampai pada tahap refleksi maka hasil refleksi akan memunculkan masalah baru yang berupa hasil evaluasi pelaksanaan tindakan pada siklus I. Langkah pertama pada siklus II adalah perencanaan, pada tahap ini peneliti dan kolaborator menentukan pokok bahasan diskusi, membuat Satuan Acara Perkuliahan (SAP) yang meng-integrasikan metode SGD berbasis peer assesment dengan perbaikan pada pengkondisian ruang kelas dan pengalokasian waktu, menyusun instrumen penelitian berupa lembar peer assesment, lembar rekapitulasi nilai peer assesment dan lembar observasi kegiatan perkuliahan.

Tahap kedua dalam siklus I yaitu pelaksanaan, langkah-langkah tindakan yang dilakukan yaitu; (1) sebelum perkuliahan dimulai, dosen mengkondisikan ruang kelas untuk kegiatan diskusi, (2) dosen membuka kegiatan perkuliahan dengan apersepsi, orientasi dan motivasi, (3) kelas dibagi dalam 10 kelompok kecil yang beranggotakan
4 orang mahasiswa tiap kelompok, (4) setiap kelompok diberi bahan diskusi yang berbeda-beda namun masih dalam satu topik materi, (5) dosen menjelaskan langkah diskusi dan peer assesment yang akan dilakukan, (6) dosen menjelaskan aspek keterampilan komunikasi lisan yang akan dinilai dalam peer assesment, (7) dosen bersama mahasiswa membuat kesepakatan untuk merencana-kan waktu diskusi, presentasi dan penilaian, (8) setiap kelompok berdiskusi sesuai dengan permasalahan dalam bahan diskusi yang diberikan, (9) perwakilan dari anggota kelompok menyampaikan hasil diskusi dan kelompok lain memberikan tanggapan, (10) pengambilan kesimpulan bersama, (11) penilaian keterampilan komunikasi lisan oleh rekan dalam satu kelompok.

Pengamatan pada tahap ketiga di siklus II dilakukan oleh peneliti dengan mengamati aktivitas mahasiswa dalam proses perkuliahan menggunakan metode SGD berbasis peer assesment. Instrumen yang digunakan berupa lembar observasi aktivitas mahasiswa. Sama seperti siklus I, akhir dari tahap siklus I adalah refleksi. Hasil refleksi pelaksanaan tindakan di siklus II yaitu; langkah perbaikan dengan melakukan pengkondisian ruang kelas dan pengalokasian waktu dapat berjalan dengan lancar dan dapat mengefektifkan proses jalannya diskusi maupun peer assesment. Mahasiswa memiliki waktu yang cukup untuk mengidentifikasi indikator penilaian sehingga dapat lebih cermat dalam melakukan penilaian teman sebaya. Hasil peer assesment menunjukkan adanya peningkatan keterampilan komunikasi lisan mahasiswa, dengan hasil rata-rata nilai keterampilan komunikasi lisan mahasiswa melalui peer assesment disajikan dalam tabel 4 sebagai berikut.

\section{Tabel 4. Data Nilai Keterampilan Komunikasi Lisan Mahasiswa Siklus II}

\begin{tabular}{cccc}
\hline Kategori & $\begin{array}{c}\text { Rentang } \\
\text { Nilai }\end{array}$ & Frekuensi & Persentase \\
\hline Terampil & $81-100$ & 10 & $25,0 \%$ \\
Cukup & $71-80$ & 22 & $55,0 \%$ \\
Kurang & $61-70$ & 7 & $17,5 \%$ \\
Gagal & $01-60$ & 1 & $2,5 \%$ \\
\hline \multicolumn{2}{c}{ Jumlah } & 40 & $100 \%$ \\
\hline
\end{tabular}

Keterampilan komunikasi lisan maha-siswa mengalami peningkatan pada pelaksanaan siklus II, terlihat dari penurunan persentase nilai keterampilan komunikasi lisan pada kategori kurang dan gagal pada siklus I sebesar $47.5 \%$ mengalami penurunan 
menjadi $20 \%$. Berdasarkan perolehan data tersebut maka dapat diketahui bahwa persentase keberhasilan tindakan telah mencapai $80 \%$ yang artinya sebanyak 32 dari 40 orang mahasiswa berada dalam kategori terampil dan cukup terampil. Sedangkan 7 mahasiswa berada pada kategori kurang terampil dan 1 orang berada dalam kategori gagal. Refleksi yang dilakukan yaitu dengan menganalisis hasil penilaian pada mahasiswa yang berada pada kategori kurang dan gagal. Hasil analisis lembar penilaian mahasiswa dengan kategori kurang dan gagal dapat dilihat pada Gambar 2.

Berdasarkan data di atas dapat diana-lisis bahwa 4 dari 7 mahasiswa (nomor induk mahasiswa: 221, 227, 230) memiliki kelemahan pada kecakapan dalam berperan sebagai presenter, kurang dapat menjelaskan dan merepresentasikan materi sehingga berpengaruh juga pada rendahnya kemampuan dalam meyakinkan orang lain dan mendorong/memotivasi tim. Tindak lanjut yang dilakukan pada keempat mahasiswa ini yaitu, dosen memberikan kesempatan lebih pada ke empat mahasiswa tersebut untuk berperan sebagai presenter dengan tujuan melatih maha-siswa untuk dapat meningkatkan kemam-puan dalam mempresentasikan, menjelaskan, meyakinkan orang lain dan memberi-kan motivasi serta dorongan pada orang lain.
Berdasarkan data di atas juga dapat dianalisis bahwa 3 dari 7 mahasiswa (nomor induk mahasiswa: $238,240,241)$ yang lain memiliki kelemahan pada sikap, data menunjukan bahwa rata-rata teman dalam satu tim tidak setuju bahwa ketiga mahasiswa tersebut merupakan pendengar yang baik, memiliki sikap yang baik, mampu membangun hubungan kerja yang baik dan mudah menerima masukan dan kritik. Tindak lanjut yang dilakukan pada ketiga mahasiswa ini yaitu, dosen melakukan pendekatan personal kepada mahasiswa melalui bimbingan dan konseling.

Selain ketujuh mahasiswa dalam kategori kurang terampil dalam komunikasi lisan, terdapat satu mahasiswa (nomor induk mahasiswa: 228) yang berada pada kategori gagal. Berdasarkan data penilaian peer assesment, diperoleh informasi bahwa mahasiswa ini lemah di hampir setiap aspek keterampilan komunikasi lisan kecuali pada aspek sikap, dimana rata-rata rekan satu tim menilai mahasiswa ini merupakan pendengar yang baik, memiliki sikap yang baik, mampu membangun hubungan tim yang baik dan mau mene-rima kritik dan saran. Tindak lanjut yang dilakukan oleh dosen yaitu melakukan pendekatan personal kepada mahasiswa. Hasil dari tindak lanjut diketahui bahwa pada saat proses tindakan pada siklus I dan II, mahasiswa ini

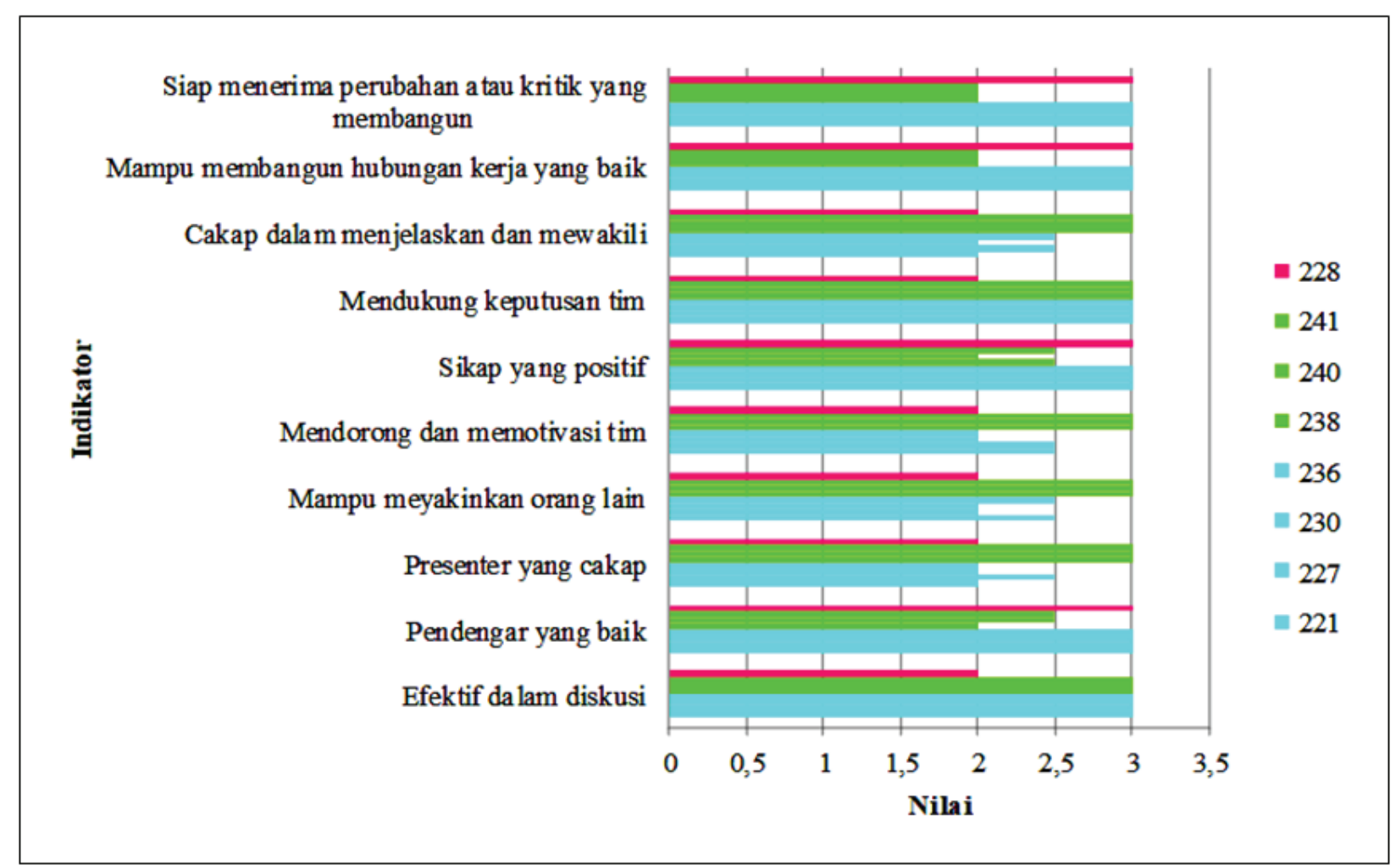

Gambar 2. Grafik Analisis Lembar Penilaian Mahasiswa dengan Kategori Kurang dan Gagal 
dalam keadaan sakit dan kurang dapat mengikuti kegiatan perkulia-han dengan maksimal. Peneliti melakukan konfirmasi kepada mahasiswa lain yang pernah berada dalam satu tim dengan mahasiswa ini dan diperoleh konfirmasi bahwa mahasiswa yang bersangkutan memang sedang dalam keadaan sakit selama proses tindakan dilakukan.

\section{PEMBAHASAN}

Penelitian ini dilaksanakan dalam dua siklus. Setiap siklus dilaksanakan dalam dua pertemuan. Tindakan yang dilakukan yaitu menerapkan metode Small Group Discussion (SGD) berbasis peer assesment pada mata kuliah Ilmu Pengetahuan Sosial (IPS) sehingga topik-topik yang didiskusikan merupakan bagian dari ilmu pengetahuan sosial. Metode SGD dalam penelitian ini dikembangkan dengan berbasis peer assesment dimana di akhir kegiatan diskusi, mahasiswa melakukan penilaian terhadap rekan dalam satu kelompok kecil. Penilaian yang dilakukan berfokus pada keterampilan komunikasi lisan. Van Roekel (2014) mengungkapkan pembinaan kompetensi komunikasi merupakan hal yang wajib pada semua proses pembelajaran.

Berdasarkan hasil pengamatan dan analisis data yang diperoleh, dapat dinyatakan bahwa penerapan metode Small Group Discussion (SGD) berbasis peer assesment dapat meningkatkan keterampilan komunikasi lisan mahasiswa PGSD kelas A6 semester 2 Universitas PGRI Yogyakarta tahun akademik 2018. Kemampuan komunikasi termasuk keterampilan dalam menyampaikan pendapat, gagasan maupun opini dengan jelas, mengajukan perintah dengan jelas serta mampu memberikan motivasi kepada orang lain melalui keterampilan berbicara (Zubaidah, 2017). Pada observasi pratindakan, diperoleh data rendahnya keterampilan komunikasi lisan mahasiswa. Sebesar $77.5 \%$ mahasis-wa belum memenuhi kriteria cukup terampil dan terampil dalam berkomunikasi secara lisan. Maka dapat diketahui bahwa mahasiswa yang cukup terampil dan terampil berdiskusi hanya $22.5 \%$ dari 40 mahasiswa. Berdasarkan hasil analisis awal tersebut, maka diperlukan adanya tindakan untuk meningkatkan keterampilan komunikasi lisan mahasiswa. Tindakan yang dilakukan yaitu dengan menerapkan metode Small Group Discussion (SGD) berbasis peer assesment. Hal ini dikarenakan komunikasi merupakan keterampilan yang sangat penting, bahkan menjadi salah satu kunci sukses dalam profesi apapun (Lunenburg, 2010).

Tindakan pada siklus I dilaksanakan dengan menerapkan metode SGD berbasis peer assesment dalam dua pertemuan dengan topik diskusi yang berbeda. Pada setiap akhir kegiatan diskusi mahasiswa melakukan peer assesment. Hasil peer assesment pada pertemuan 1 dan 2 kemudian direkapitulasi dan dianalisis oleh peneliti. Hasil analisis data keterampilan komunikasi lisan mahasiswa pada siklus I menunjukkan bahwa persentase mahasiswa pada ketegori cukup terampil dan terampil mengalami peningkatan dibandingkan dengan data nilai pratindakan. Peningkatan keterampilan komunikasi lisan sebesar 30\%. Dari 22.5\% meningkat menjadi $52.5 \%$. Hasil refleksi siklus I menunjukkan adanya kekurangan pada pelaksanaan tindakan siklus I yaitu kurang efektifnya pengkondisian ruang kelas dan pengalokasian waktu sehingga durasi waktu dalam pelaksanaan peer assesment sangat terbatas sehingga menyebabkan mahasiswa kurang dalam menganalisis butir-butir penilaian dalam peer assesment. Hasil refleksi kemudian dijadikan sebagai perbaikan pada pelaksanaan siklus II.

Bercermin dari pelaksanaan perkuliahan pada siklus I, maka penelitian dilanjutkan pada siklus II dengan mengacu pada hasil refleksi siklus I. Terdapat beberapa perbaikan dalam proses perkuliahan yaitu dengan melakukan pengkondisian ruang kelas untuk kegiatan diskusi sebelum kegiatan perkuliahan dimulai, membuat kesepakatan dengan mahasiswa untuk membuat batasan waktu pada setiap kegiatan dan menyampaikan hasil penilaian peer assesment kepada mahasiswa secara personal disertai motivasi dan penguatan untuk meningkatkan keterampilan komunikasi. Kemampuan memberikan motivasi kepada orang lain melalui keterampilan berbicara merupakan salah satu bagian dari kemampuan komunikasi yang perlu dikembangkan (Zubaidah, 2017).

Hasil analisis pada siklus II menunjukkan adanya peningkatan keterampilan ko-munikasi lisan mahasiswa. Peningkatan keterampilan komunikasi lisan sebesar $27.5 \%$ jika dilihat dari hasil siklus I, dan mengalami peningkatan sebesar $57.5 \%$ jika dilihat dari data pra tindakan. Hasil analisis peer assement keterampilan komunikasi lisan mahasiswa menunjukkan bahwa sebesar $80 \%$ mahasiswa berada pada kategori cukup terampil dan terampil berkomunikasi secara lisan. Data perbandingan nilai 
keterampilan berdiskusi mahasiswa sebelum tindakan, siklus I dan siklus II dapat dilihat pada Gambar 3.

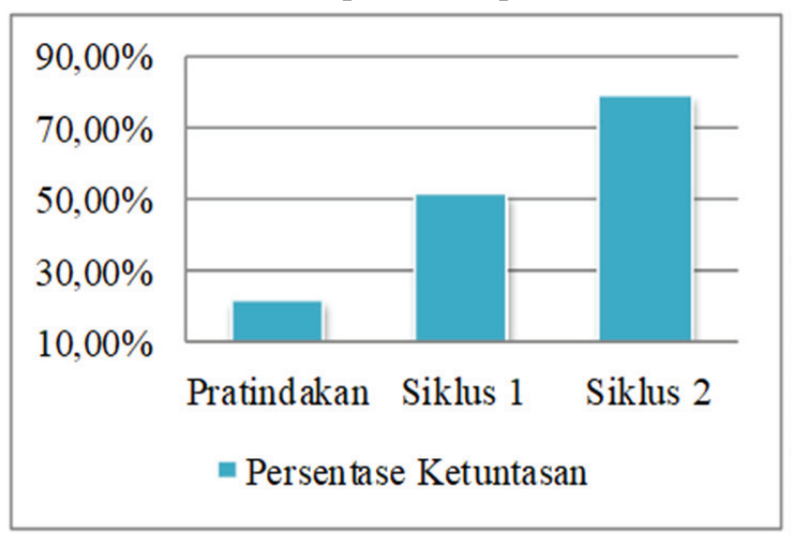

\section{Gambar 3. Perbandingan Persentase Ketuntasan Keterampilan Komunikasi Lisan}

Diagram batang tersebut menunjukkan peningkatan persentase keterampilan ko-munikasi lisan mahasiswa PGSD UPY kelas A6 semester 2 dimana pada tahap pratindakan mahasiswa yang termasuk dalam kategori terampil berdiskusi sebanyak $22,5 \%$ kemudian persentase tersebut meningkat pada saat dilakukan tindakan pada siklus I menjadi 52,5\% dan kem-bali menunjukan peningkatan pada siklus II sebesar 80\%. Berdasarkan pembahasan hasil penelitian di atas, maka dapat dikatakan bahwa dengan menerapkan metode Small Group Discussion (SGD) berbasis peer assesment dapat meningkatkan keterampilan komunikasi lisan mahasiswa kelas A6 S1 PGSD FKIP UPY. Hal ini sejalan dengan tuntutan bagi guru abad 21 yang diharuskan untuk mampu membangun hubungan baik dengan siswa maupun kemunitas sekolah (Darling-Hammond, 2006). Pentingnya penguasaan keterampilan komunikasi di abad 21, akan dapat mengembangkan keterampilan komunikasi peserta didik masa depan.

\section{SIMPULAN DAN SARAN}

\section{Simpulan}

Berdasarkan hasil penelitian dan pembahasan, maka dapat disimpulkan bahwa penerapan metode Small Group Discussion berbasis peer assesment dapat meningkatkan keterampilan komunikasi lisan mahasiswacalon guru sekolah dasar. Halinidisebabkan penerapan metode SGD berbasis peer assesment memiliki kelebihan terutama dalam peningkatan keteram-pilan komunikasi lisan mahasiswa terutama dalam meningkatkan kemampuan berkomunikasi dalam diskusi, mempresentasikan hasil diskusi, menjelaskan dan merepresentasikan materi dan membangun hubungan baik dengan anggota kelompok. Melalui kegiatan diskusi kelompok kecil yang mengintegrasikan proses peer assesment, maka akan memicu tuntutan mahasiswa untuk berfikir dan bertindak secara maksimal.

\section{Saran}

Dengan memperhatikan simpulan di atas, maka peneliti dapat menyampaikan saran-saran sebagai berikut. Dosen PGSD perlu mengkaji lebih lanjut tentang metode Small group Discussion dan peer asses-ment sehingga dapat menerapkan metode tersebut secara maksimal dalam mening-katkan keterampilan komunikasi lisan mahasiswa. Selain itu, dalam proses perku-liahan perlu dibuat materi/ bahan ajar yang dapat dilakukan dengan menerapkan metode SGD. Dalam proses perkuliahan, mahasiswa perlu dimotivasi salah satunya dengan menggunakan metode SGD berbasis peer assesment sehingga mahasiswa dapat berperan aktif dalam proses perkuliahan dan terlibat langsung dalam proses penilaian. Mengingat pentingnya keterampilan komunikasi lisan, maka mahasiswa perlu terus memotivasi diri dan berpartisipasi secara aktif dalam proses perkuliahan. Metode SGD merupakan alternatif metode perkuliahan yang dapat meningkatkan keterampilan komunikasi lisan mahasiswa calon guru sekolah dasar.

\section{DAFTAR RUJUKAN}

Barry, M. (2012). What skills will you need to succeed in the future? Retrieved June 27, 2018, from Pheonix Forward website: www.phoenix.edu/ forward/careers/2012/09/what-skills-willyou$\% 0$ Aneed-to-succeed-in-the-future.html

Bolstad, R. (2011). Taking a "future focus" in education - what does it mean ? In An NZCER working paper from the Future-Focused in Education (FFI) project.

Darling-Hammond, L. (2006). Constructing 21stcentury teacher education. Journal of Teacher Education, 57(3), 300-314. https://doi. org/10.1177/0022487105285962

Dass, R. (2014). Literature and the 21st century learner. Procedia - Social and Behavioral Sciences, 123, 289-298. https://doi. org/10.1016/j.sbspro.2014.01.1426

Falchikov, N. (1991). Involving students in feedback 
and assessment: a report from the assessment strategies in scottish higher education (ASSHE) project (S. Brown, Ed.). Birmingham: Staff and Education development Association.

Falchikov, N. (2003). Involving students in assessment. Psychology Learning and Teaching, 3(2), 102-108.

Griffin, P., McGaw, B., \& Care, E. (2012). Assessment and teaching of 21st century skills. Dordrecht, NL: Springer.

Iskandar. (2013). Metodologi penelitian pendidikan sosial. Jakarta: Referensi.

Logan, E. (2009). Self and peer assessment in action. Practitioner Research in Higher Education, 29-35.

Lunenburg, F. C. (2010). Communication : The Process , Barriers , And Improving Effectiveness. Schooling, 1, 1-11.

Marcus, B., \& Curt, C. (2017). First, break all the rules. Jakarta: Pustaka Alvabet.

McCann, I., \& Radford, R. (1993). The return of the mentor: Strategies for workplace learning (J. B. Caldwell \& M. A. Carter, Eds.). Washington DC: The Falmer Press.

Mustadi, A. (2014). Peningkatan kompetensi active speaking mahasiswa melalui model communicative language pada mata kuliah bahasa Inggris di PGSD. Dinamika Pendidikan, 21(1), 103-122.

Nortcliffe, A. (2012). Can students assess themselves and their peers? - A five year study. Student Engagement and Experience Journal, 1(2), 1-17. https://doi.org/10.7190/seej.v1i2.29

Orsmond, P., Merry, S., \& Reiling, K. (1996). The importance of marking criteria in the use of peer assessment. Assessment and Evaluation in Higher Education, 21(3), 240-250. https://doi. org/10.1080/0260293960210304
Pellegrino, J. W., Hilton, M. L., Deeper, D., Skills, C., Testing, B., Education, S., ... Sciences, S. (2012). Education for Life and Work. https:// doi.org/10.17226/13398

Roberts, T. S. (2005). Self, Peer, and Group Assessment in E-Learning: An Introduction. Self, Peer and Group Assessment in E-Learning, $1-16$.

Saavedra, A. R., \& Opfer, V. D. (2012). Teaching and learning 21 st century skills: Lessons from the learning sciences. AARE-APERA 2012 - Joint International Conference of the Australian Association for Research in Education and the Asia Pacific Educational Research Association - Regional and Global Cooperation in Educational Research, (April), $1-35$.

Slavin, R. E. (2011). Psikologi pendidikan: Teori dan praktik. Jakarta: PT Index.

Trilling, B., \& Fadel, C. (2009). 21st century skills: learning for life in our times. San Francisco: Jossey-Bass/John Wiley \& Sons, Inc.

Van Roekel, D. (2014). Preparing 21st Century Students for a Global Society: An Educator's Guide to the "Four Cs ." In National Education Association.

Wagner, T. (2008). The Global Achievement Gap: Why Even Our Best Schools Don't Teach the New Survival Skills Our Children Need-And What We Can Do About It. New York: Basic Books (A Member of the Perseus Books Group).

Zubaidah, S. (2017). Keterampilan abad ke21: Keterampilan yang diajarkan melalui pembelajaran. Seminar Nasional Pendidikan Dengan tema "Isu-Isu Strategis Pembelajaran MIPA Abad 21," (June), 3. 